\title{
28. starptautiskā Baltijas zinātņu vēstures konference Tartu 2017. gada maijā
}

No 2017. gada 18. līdz 20. maijam 28. starptautiskā Baltijas zinātņu vēstures konference notika Tartu, senajā Igaunijas universitātes pilsētā. Ja atskatāmies vēsturē, Baltijas zinātņu vēstures konferences notiek jau gandrīz 70 gadus - 1958. gada jūnijā pēc Paula Stradiņa ierosmes Rīgā sanāca pirmā šāda veida pasākuma dalībnieki. Konferences notiek ik pēc diviem trim gadiem vienā no trijām Baltijas valstīm. Tartu konference notika jau astoto reizi. Katrai konferencei parasti ir kāda tematiska ievirze tās ir veltītas vai nu kādas augstskolas, vai kāda zinātnieka, biedrības vai kādas citas organizācijas atcerei. Kārtējās - 28. konferences tēma bija "Uz Krievijas impērijas robežas: vācu Tartu Universitāte un tās pirmais rektors Georgs Frīdrihs Parrots".

Kas tad bija Georgs Frīdrihs Parrots (1767-1852), kura 250. jubilejas gadā tikās zinātņu vēsturnieki? Franču izcelsmes fiziķis, atjaunotās Tartu (Tērbatas, Jurjevas) Universitātes pirmais rektors (1802-1803, 1805-1806, 1812-1813), Pēterburgas Zinātņu akadēmijas akadēmiķis (1826). Daži viṇa mūža gadi ir saistīti ar Latviju - 1795. gadā viņš ieradās Vidzemē un strādāja par mājskolotāju muižnieka Karla Berharda fon Zīversa ǵimenē Cēsīs. Drīz vien G. F. Parrots tika ievēlēts par Vidzemes vispārderīgās ekonomiskās biedrības sekretāru un pārcēlās uz dzīvi Rīgā. Te viņš veica dažādus eksperimentus: pārbaudīja gaisa sastāvu, eksperimentēja ar elektriskās strāvas galvaniskajiem avotiem, aprakstīja pirmā medicīniskā termometra principu. Turklāt G. F. Parrots iestājās par dzimtbūšanas atcelšanu Baltijas guberņās un veicināja zemnieku likumu pieņemšanu. Ar tagadējās Latvijas teritoriju saistīta viņa ǵimene - Sv. Jēkaba baznīcā Rīgā 1796. gadā Georgs 
Frīdrihs salaulājās ar otro sievu, savukārt viņa dēls Vilhelms Frīdrihs Parrots (1790-1882), mācītājs Burtniekos (1817-1860), laulājās šajā baznīcā 1818. gadā. Rīgas pilsētas teātra mākslinieciskais direktors (1869-1874) bijis Georga Frīdriha mazdēls Pīrss Frīdrihs Parrots (1838-1925). Otrs viņa mazdēls, vēlākais fiziķis Morics Frīdrihs Parrots (1831-1882), mācījās privātajā Bērzaines ğimnāzijā pie Cēsīm. Viens no G. F. Parrota dēliem ir mācījies Rīgas Doma skolā. Tie ir vēstures fakti, kas slaveno fiziķi un Tartu Universitātes rektoru liek pieminēt mūsdienu Latvijā. Par zinātnieka saistību ar Rīgu, Cēsīm un tajās dzīvojošajām personībām konferences dalībniekus iepazīstināja Rīgas Tehniskās universitātes asocietā profesore Alīda Zigmunde.

Konferencē Latviju pārstāvēja seši delegāti: pieci no viņiem saistīti ar medicīnas vēsturi un Rīgas Stradiṇa universitāti - docente Ieva Lībiete, docente Maija Pozemkovska un profesors Juris Salaks Baltijas zinātņu vēstures konferencēs piedalījušies jau vairākkārt, bet doktorante Sabīne Lauze un pirmā kursa students Romualds Gerulis-Bergmanis - pirmo reizi. Ieva Lībiete bija sagatavojusi referātu par Rīgas ārsta un vēlākā Tartu Universitātes rektora Ernsta Martina Stiksa cīņu pret pārmērīgu asins nolaišanu Latvijas teritorijā 18. gs. beigās. Juris Salaks runāja par Tērbatas Universitātes profesoru institūta izveides projektu, kuru realizēja G. F. Parrots. Par Apgaismības laikmeta etnogrāfa, mākslinieka, vēsturnieka un G. F. Parrota laikabiedra Johana Kristofa Broces zīmējumiem, kuri saistāmi ar medicīnas vēstures pieminekḷiem, referēja Maija Pozemkovska un students Romualds Gerulis-Bergmanis. Doktorante Sabīne Lauze bija sagatavojusi referātu par farmaceitu asistentu kursiem laikā no 1940. līdz 1945. gadam.

Tradicionāli konferencē piedalās ne tikai Baltijas valstu zinātņu vēsturnieki. Šoreiz referātus bija pieteikuši zinātņu vēsturnieki no ASV, Francijas, Krievijas, Polijas, Somijas, Šveices, Ukrainas un Vācijas. Konferences programmā bija paredzēti 69 referāti, no kuriem nolasīti tika 58. Igauņi bija sagatavojuši 19 referātus, kas ir gandrīz trešdaḷa no kopskaita, savukārt lietuvieši - desmit referātus. Diemžēl sagatavoto referātu par Georgu Frīdrihu Parrotu un latviešu studentiem nenolasīja medicīnas vēsturnieks, ilggadējais konferenču dalībnieks Arnis Vīksna. Ne visi referāti bija saistīti ar fiziķa G. F. Parrota dzīvi un darbību, jo zinātņu vēsturnieki pēta ļoti dažādus un bieži vien pat ar Baltiju nesaistītus jautājumus. Neiztika arī bez mūsdienām, piemēram, Tallinas Tehniskās 
universitātes profesors, bijušais Tartu Universitātes rektors Jāks Āvikso runāja par 21. gadsimta izaicinājumiem, ar kādiem universitāte saskaras izglītības un zinātnes jomā. Konferences tēzes šoreiz pieejamas tikai digitālā formā. ${ }^{1}$

Tradicionāli konference noslēdzās ar ǵenerālo asambleju. Tajā tika saņemta patīkama ziņa - Igaunijas Zinātņu vēstures un filozofijas asociācijas sadarbībā ar Latvijas un Lietuvas Zinātņu vēstures un filozofijas asociāciju izdotais (no 2013. gada) starptautiskais zinātniskais žurnāls anglu valodā Acta Baltica Historiae et Philosophiae Scientiarum 2016. gada novembrī tika iekḷauts Scopus datubāzē.

Konferences laikā bija iespēja iepazìt Tartu Universitātes muzeju un tā filiāles, kā arī apmeklēt jaunatklāto Igaunijas Nacionālo muzeju. Turklāt emeritētie igauņu zinātnieki konferences dalībniekus aicināja 2017. gada vasarā doties cel̦ojumā "Pa Georga Frīdriha Parrota pēdām”, apmeklējot ievērojamā zinātnieka dzimto pilsētu Monbeljāru Francijas austrumos, taču atsaucība bija neliela. Daudzi jau bija saplānojuši atvaļinājuma laiku, turklāt uz Monbeljāru nav tiešas satiksmes no Baltijas valstīm, kas ceļojumu gan paildzina, gan sadārdzina.

\footnotetext{
Alīda Zigmunde

Dr. paed., Rīgas Tehniskās universitātes Humanitārais institūts, asociētā profesore /

The Institute of Humanities at Riga Technical University, Assoc. Professor
}

1 Abstracts of the XXVIII International Baltic Conference on the History of Science (Tartu: Tartu University, 2017), 56, http://dspace.ut.ee/bitstream/handle/10062/56393/ abstracts_2017.pdf?sequence $=4 \&$ isAllowed $=\mathrm{y}$. 